\title{
IMPROVING RESILIENCE IN ARCHITECTURAL HERITAGE? THE RECONSTRUCTION OF THE VAULTING SYSTEMS AFTER THE 1805 EARTHQUAKE IN MOLISE (ITALY)
}

\author{
L. Romano ${ }^{1, *}$ \\ ${ }^{1}$ Dept. of Architecture, Università degli Studi di Napoli Federico II, Naples, Italy - lia.romano2@unina.it
}

Commission II - WG II/8

KEY WORDS: Wooden Vaults, Unreinforced Concrete Vaults, Tile Vaults, Hollow Clay Pot Vaults, Resilience, Reconstruction

\begin{abstract}
:
The 1805 earthquake damaged a large area of the Southern Italy, destroying most of the architectural heritage in the "Contado of Molise", a poor region characterized by numerous medieval towns. In the aftermath of the catastrophe, the reconstruction and in fewer cases the restoration of important buildings, mainly the ecclesiastical ones, took place without a well-defined rebuilding plan. If, from a formal point of view, interesting design levels were not reached, the same cannot be stated for the construction solutions adopted, especially regarding vaulted systems. Actually, they were conceived either with wood, concrete with aggregates or full/hollow clay bricks. This variety of constructive raw elements is a direct manifestation of the richness of the vernacular constructive tradition. Moreover, the intrinsic lightness of such materials suggests as well the need at the time of new lightweight structures capable of standing on pre-existing weakened masonries. This approach was probably taken in order to reduce vulnerability and improve structural resilience to earthquakes. In light of these considerations, the paper focuses on the different construction techniques used to rebuild the vaulting systems after the 1805 earthquake in Molise, discussing their potentialities and weaknesses as well as their capacity to improve resilience in the architectural heritage.
\end{abstract}

\section{INTRODUCTION}

On July 26, 1805 a violent earthquake damaged a large area of Southern Italy, in particular the Contado of Molise, one of the most underdeveloped regions in the Kingdom of Naples ${ }^{1}$. The earthquake completely destroyed the majority of the important buildings in urban centres, e.g. churches and palaces belonging to local aristocracy. Reconstruction and, in fewer cases, restoration followed (Antinori, 2006; Zullo, 2009). Starting from 1806 - despite the lack of a rebuilding programme - a lot of construction yards linked to the ecclesiastical and civil architectures opened. The new projects, which mainly concerned the ecclesiastical heritage in the case of small urban centres, were implemented by master builders, self-styled architects and only after the Restoration, started with the Vienna Congress, by engineers from the Scuola di Ponti e Strade of Naples (Zullo, 2009). During this period, the relationships between the two professional classes, the first being representative of a more empirical approach to construction compared to the rigorous scientific engineering culture, was strengthened, generating a fruitful dialogue and an interweaving of skills that can be clearly observed in the technical solutions adopted, often "mixed", between tradition and innovation.

If from a formal and compositional point of view interesting design levels were not reached - in most cases attempts were made to integrate pre-existing baroque elements into new architectures (Antinori, 2006; Antinori 2007; Zullo, 2009) - the same cannot be said for the construction solutions adopted, especially regarding vaulted systems.

\footnotetext{
* Corresponding author

1 The study presented in this paper is part of the author's doctoral thesis (see References). For further information on the management of the emergency phase and the first reconstruction interventions on the urban scale see also: Romano 2016a and 2016b.
}

The analysis of the projects and in particular of the bills of quantities highlights the main construction techniques which were employed. New vaults were made up of several materials such as wood, concrete with aggregates together with both full and hollow bricks. A variety of techniques which manifests the richness of the building tradition, sometimes vernacular, and which appears to be influenced by economic reasons and by the availability of materials on site. In addition, the need for lightweight structures able to stand on fragile pre-existing buildings and to avoid the collapse of the same due to horizontal thrusts in case of a new earthquake, could have played an important role in the decision process.

The use of lightweight materials in the reconstruction of vaulted systems following earthquakes does not appear to be a new theme in the panorama of central-southern Italy, as pointed out, for example, by the studies on the earthquakes that struck the Val di Noto in 1693 (Nobile, 2004), Palermo in 1726 and 1823 (Nobile, Bares 2015; Scibilia, 2016) or Abruzzo in 1703 (Carocci, Tocci, 2016, Ghisetti Giavarina, 2016; Varagnoli, 2008). As a matter of fact, the construction of vaulted systems with light materials was considered a valid alternative, also from an economic point of view, to the consolidation of preexisting coverings or to the rebuilding based on sole heavy stones. Considering, therefore, the intrinsic vulnerability of the vaulted systems, the decision to build lightweight structures much less pushing on the perimeter walls than the traditional heavy vaults - could have seemed a valid solution to be adopted at the time. In particular, it is possible to observe still nowadays, especially in the abandoned centres of the Apennines, numerous fake wooden vaults which are still standing, proof of their ability to cope with telluric movements (Serafini, 2009). 
After the earthquake in Molise - differently from the case of the Calabria region at the end of the 18th century where potential anti-seismic systems were developed - no guidelines or criteria for reconstruction were defined. The only indications, concerning the quality of the binders and the composition of the masonry, were given, in a purely theoretical way, by Pasquale Fortini in his text on the damage observed in the town of Isernia (Fortini, 1984). The reconstruction did not represent, at least in appearance, an opportunity for renewal from a formal and constructive point of view. However, through the analysis of the metric calculations, some data emerge which testify, if not a real awareness, at least a certain cognisance of the "earthquake problem". Despite the great availability of limestone in the area, in fact, new vaults were rarely rebuilt with this material. In most cases, light elements were used, due to the need to not overstress the pre-existing masonries.

The territory under investigation corresponds to the area most affected by the earthquake of 1805 between the cities of Campobasso and Isernia. The research, therefore, focuses mainly on the Lower Molise region and excludes the Adriatic coast and the centres on the Abruzzo, Lazio and Apulia slopes, the latter most affected by the 2002 earthquake. In this regard it is significant to point out that the earthquake of 1805 was the last catastrophe that struck the Bojano plain and the neighbouring territories, situated in correspondence of a complex system of faults, responsible, moreover, with that of Benevento and the Meta mountains, for the tragic earthquake that struck a vast portion of central-southern Italy in 1456. It is a territory, for that reason, at great seismic risk, characterised, as also the 2002 earthquake demonstrated, by a particularly vulnerable architectural heritage.

This research, hence, aims at providing a framework of knowledge which, although not exhaustive, can be a useful tool for the definition of restoration and seismic improvement interventions. The study mainly focuses on ecclesiastical architecture and on some more documented civil buildings, given the lack of archival data on minor and vernacular constructions. Due to the impossibility or difficulty of observing the extradoses of the vaulted structures under examination, the study is mainly based on a documentary research, with the opportunity, in some cases, of a comparison between archival data and direct observations in situ.

\section{THE RECOGNITION OF THE CONSTRUCTION FEATURES}

\subsection{Wooden vaults}

In addition to the well-known wooden vaults (so-called incannucciate) already widespread in the 18th century in the Neapolitan area and in other contexts of southern Italy (Abruzzo, Campania, Sicily), the Molise case recorded the use of a variation of the traditional wooden vault, characterised by higher resistance thanks to the presence of a lime and gypsum coat at the extrados and called a colo di gesso. The adoption of this construction system appears to have been ascertained, through direct investigations and archival documents, in numerous ecclesiastical architectures in Molise. The structure of the vault is composed by beams arranged longitudinally called filagne, by a frame of stakes (jattole or ghiatte and contrasti) and by a layer of reeds (stuoiato) covered by a coat of gypsum and lime. The stuoiato was produced through the use of good quality reeds which, depending on the cut and the intersection between the parts, could appear more or less complex and refined (Figure 1).
In the archival documentation they are defined as "strong enough to walk on, and light" even if highly vulnerable and subject to sudden collapse if not well built. Moreover, the system is partially suspended, through thin wooden rods, called rielle, from the truss roof above.
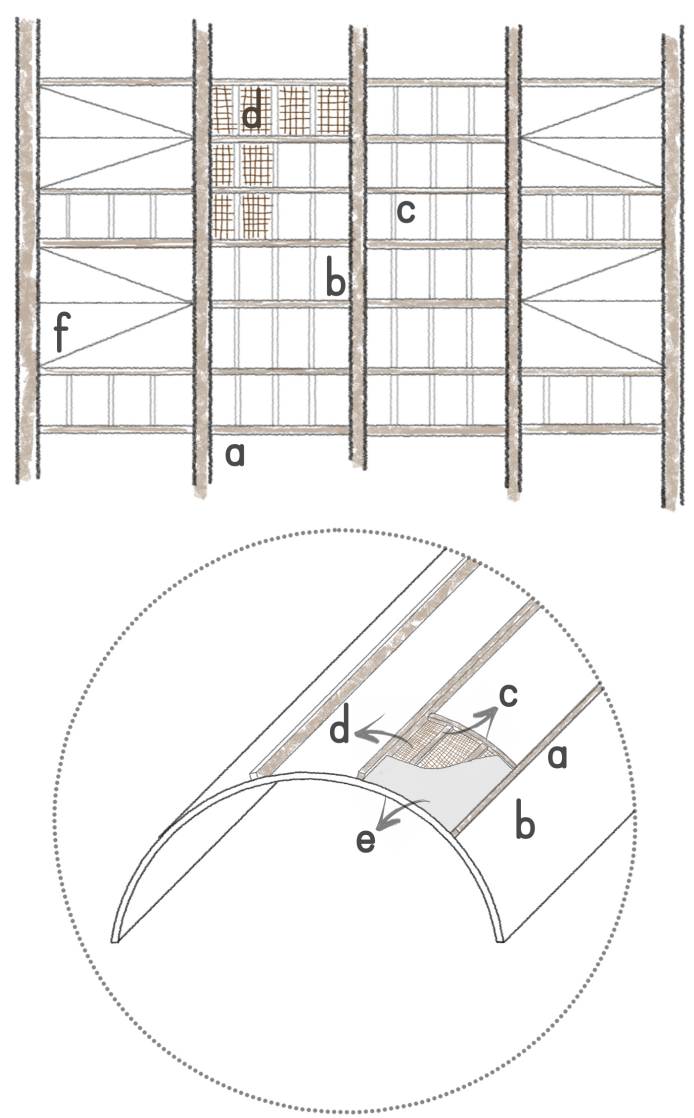

Figure 1. Explanatory sketch of the wooden vaults: plan and axonometry. Legend: a: filagne; b: jattole; c: contrasti; d: stuoiato (reeds); e: lime\&gypsum coat; f: lunettes (Romano).

Despite some critical issues, it should be pointed out that the lightness of the construction system made it particularly suitable to be used on fragile and pre-existing buildings. Moreover, the presence of the gypsum coat on the intrados and extrados justified its greater resistance compared to the classic wooden vaults and served to protect the structure from deterioration. This improvement was also proposed by the architect Leonardo Massimiliano de Vegni, author of an interesting essay published in the journal Memoria per le belle arti in which, dealing with wooden vaults, he proposed various methods to increase their durability, including that of plastering the structure with gypsum and calcine (de Vegni, 1788).

The technique was employed in many ecclesiastical and civil buildings in Molise including the cathedral of Bojano (Campobasso, project of 1807), the cathedral and the Collegio Sannitico in Campobasso and the church of San Michele Arcangelo in Baranello (Campobasso).

\footnotetext{
«forti fino a poterci camminare sopra, e legiere», State Archive of Campobasso, Intendenza di Molise, b. 300, f.lo sn, Manifesto delle condizioni di appalto, 2 September 1814.
} 
The project for the church of the SS. Trinità of Campobasso was drawn up by the engineer Bernardino Musenga in August 1813. Despite the project being missing from the archival documentation available, it is possible to infer the materials and construction techniques used at the time via the analysis of the expense notes and the correspondence between Musenga, the Molise Intendenza and the Ministry of the Interior. The technician proposed wooden vaults (a colo di gesso), albeit some detractors warned about the actual resistance of this construction system, especially in the case of heavy stucco decorations ${ }^{3}$.

In 1812, following the invitation of the Ministry of the Interior Giuseppe Zurlo, the same engineer also designed the church of Baranello, town at the epicentre of the earthquake. In this case, it was possible to inspect the extrados of the nave vault and, therefore, to study its structure and materials: as in the previous case, it consists of a "mixed" vault made of wood and lime/gypsum coat. Unlike the church of the SS. Trinità of Campobasso, however, where the main frame was covered with wooden planks, in this case reeds were used, perhaps due to the availability of the material on site.

The barrel vault with lunettes covers the nave, measuring about 8 x 14 metres and resting on vertical partitions 80 centimetres thick (Figure 2).The wooden structure, consisting of four filagne, shapes the form of the vault and the side lunettes generated by three small wooden stakes (jattole or ghiatte) connected to the longitudinal elements. Each filagna is joined to the truss, made up of seasoned oak wood, by the rielle ${ }^{4}$ (Figure 3 ).

In addition to Neapolitan engineers, the wooden-gypsum vaulted system was also adopted by local master builders, demonstrating the strong interconnection between vernacular building traditions and the solutions adopted by the cultured technical class, more exposed to innovations from France in the field of construction.

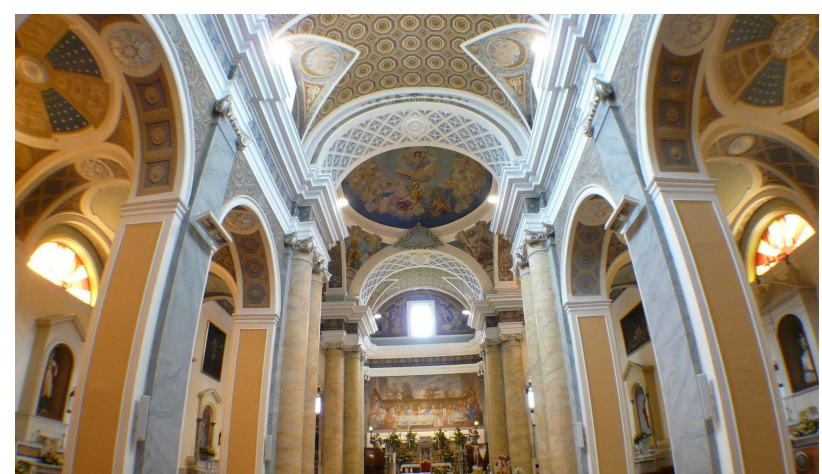

Figure 2. Baranello (Campobasso). Church of St. Michele Arcangelo: the main nave (Romano, 2016).

This is the case of the vaults of the church of Santa Croce in Vinchiaturo (Campobasso) designed in 1810 by the two master builders Pasquale Iarossi and Michelangelo Iacobucci and subject to consolidation in the following decades ${ }^{5}$.

State Archive of Campobasso, Intendenza di Molise, b. 300, f.lo s.n., Lettera del 9 agosto 1824.

4 The truss was subject to a partial renovation in the $1850 \mathrm{~s}$, State Archive of Naples, Ministero degli Affari Interni, II versamento, b. 3594 , f.lo 850.

5 State Archive of Campobasso, Intendenza di Molise, b. 924, Perizia del 20 febbraio 1819.

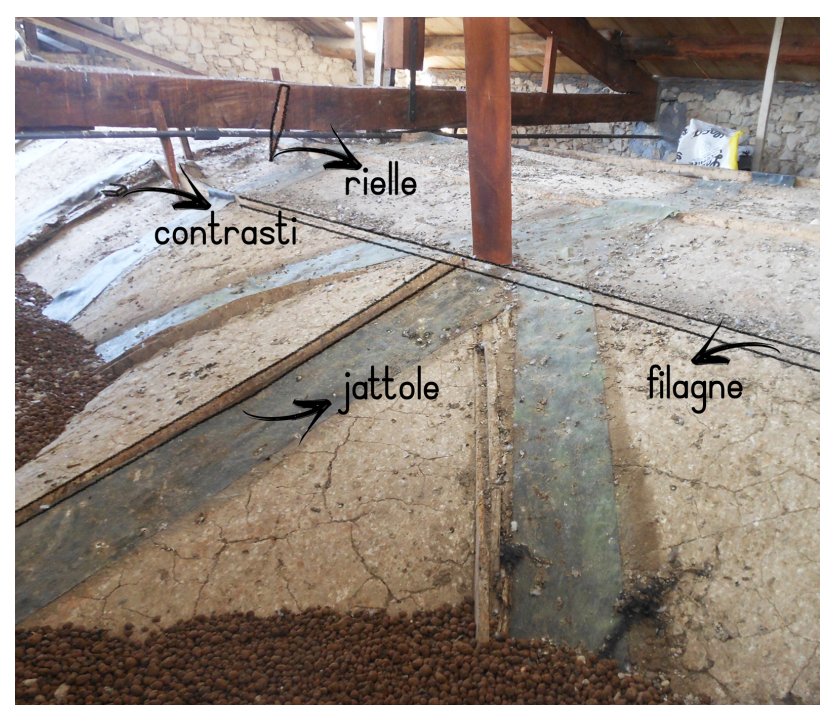

Figure 3. Baranello (Campobasso, Italy), Church of St. Michele Arcangelo: extrados of the wooden vault covering the central nave (Romano, 2016).

\subsection{Unreinforced concrete vaults}

In addition to wood, another material available on site and used both for the construction of vertical partitions as well as in vaults was the cimento, defined in the archive documentation as "spongy and light tuff known under the name of water cement". With this material, after the earthquake, "strong vaults" able to "fight with eternity"7 resisting humidity and meteoric infiltrations were built.

Like pumices of volcanic origin - even if of greater weight - the cimento can be classified in the category of particularly porous and light natural stones and, therefore, by virtue of this last characteristic, advantageous for the realization of unreinforced concrete vaults. It can be considered as a legacy of the ancient Roman opus caementicium, which can be found in many churches in the region such as Frosolone (Isernia) and Bojano (Campobasso).

The master builder Pasquale Alonzo, in the technical report on the reconstruction of the church of the Civita Superiore of Bojano (Campobasso), presented different and possible solutions for the reconstruction of the vault, comparing the costs of materials and the inherent vulnerability factors of the systems $^{8}$. The wooden vaults, in his opinion, appeared preferable in residential building to cover small spans and not large ones like in a church. In addition, the presence of wood and the potential contact with atmospheric agents, as wind and rain, significantly would increase the probability of degradation phenomena, for example the rotting of the filagne and the potential collapse of the structure. Lightness, in this case, did not seem to be a valid reason to prefer such construction system, whose weaknesses were considered comparable to the ones affecting wooden false ceilings, covered with canvas and decorated on the intrados.

6 «tufo spongoso e leggiero conosciuto sotto il nome di cemento di acqua», State Archive of Campobasso, Intendenza di Molise, b. 300, f.lo s.n. Opere pubbliche. Ricostruzione della chiesa della SS. Trinità, 1813-1825.

«lamie forti» and «combattere coll'eternità», State Archive of Campobasso, Intendenza di Molise, b. 244, f.lo s.n. Bojano, chiesa Civita, accomodi alla chiesa, 1823.

8 State Archive of Campobasso, Intendenza di Molise, b. 244, f.lo s.n. Bojano, chiesa Civita, accomodi alla chiesa, 1823. 
Leaving aside the brick vaults, considered too expensive for a small ecclesiastical building like the one in the Civita of Bojano, the sole solution for the technician was individuated in the cimenti, a stone probably belonging to the travertine family (Penta 1935), particularly porous and lighter than the white and pink limestone, widespread in the lower Molise and referred as pietraviva in the archival documentation (Figure 4).

The term cimento, which nowadays seems to be no longer in use in the vocabulary of the region, is particularly interesting because of its semantic proximity to the ancient Roman opus caementicium. The word caementum, in fact, would derive from the Latin verb caedere with the meaning of "to cut, to square" and could indicate broken objects and fragments, or the well-known caementa, materials of different types and sizes, used as lightening in opus caementicium ${ }^{9}$. In the case of Molise, the cimento, also defined as "light and spongy tuff"10 or "water cement"11, appears as an irregular, porous and, if not particularly light, certainly less heavy material than limestone.

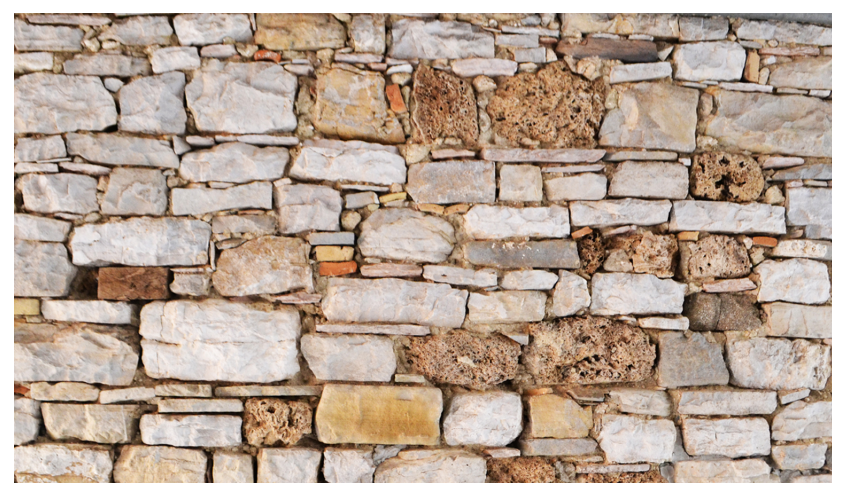

Figure 4. Frosolone (Isernia, Italy): the photo shows a masonry of limestone and cimenti (Romano, 2016).

Although it was not possible to examine the extradoses of all the buildings under study and take a sample of the material, the presence in the concerned area of a stone that perfectly fits the descriptions of the cimenti in the documentation supports the hypothesis that such local stone may have been adopted for both the construction of vaults and vertical partitions in the Molise area. Unfortunately, it is not possible to infer from the expense reports whether the vaults are in concrete or made up of cimenti ashlars. Both solutions are described by the roman architect Giuseppe Valadier in his treatise, demonstrating the strong diffusion of this types of vault in the territory of central-southern Italy (Valadier, 1828-39). The roman technician, as well as other architects of the time, specified that the different methods of implementation depended on the size of the splinters or the ashlars. The splinters could be mixed into a conglomerate with lime and sand, stiffening the structure with brickwork arches. The ashlars, instead, could be laid lengthwise or vertically using few mortar but avoiding, if possible, too thin thicknesses (de Vegni, 1788).

\footnotetext{
9 For the etymology of the term caementum see the Italian Encyclopedia Treccani under "cemento".

10 "tufo legiero e spongoso", State Archive of Campobasso, Intendenza di Molise, b. 300, f.lo s.n. Opere pubbliche. Ricostruzione della hiesa della SS. Trinità, 1813-1825.

11 "cemento di acqua".
}

The use of the cimento appears widespread in numerous ecclesiastical and civil buildings in the region such as the parish church in Sant'Elena Sannita (Isernia) and the cathedral of Isernia (Figure 5).

In the 1812 project, the master builders Nicola d'Orsi and Francesco di Cesare proposed to employ the cimenti for the vaults of the central and side naves and wood for the dome ${ }^{12}$. This expertise, revised in 1813 by the architect Bernardino Musenga, was not followed by the repair and restoration work that began many years later and ended in 1851 (Zullo, 1996).

"Stones of little weight, vulgarly called cimenti" ${ }^{13}$ were also used in 1815 for the construction of the dome of the bell tower of the parish church of Guardiaregia, based on the expertise of the mason Antonio Pallotta and a drawing by Benedetto Di Tullio $^{14}$ (Zullo, 2009).

A similar procedure was followed in the reconstruction of the church in Cantalupo nel Sannio (Isernia). In this case, in 1828, an engineer-architect, Nicolangelo Petitti, ex-officer of the Genius, was commissioned to draw up the project. In the same period, he was also involved in the work on the cathedral of Campobasso, following the death of the architect Bernardino Musenga. Despite the fact that he was not an engineer trained at the Scuola di Ponti e Strade in Naples, he showed great technical competence and precision in his work.

The project of the ecclesiastical building provided for the enlargement of the same, in a state of ruin since the earthquake of 1805 , and for the construction of vaults made up of cimenti and brick arches. If for the foundations and vertical partitions the use of «pietraviva stone» was envisaged, for the vaults of the nave and side aisles and for the elliptical cap, the cimento was employed. The same material was also used for the realization of the cornices ${ }^{15}$. In 1831 Petitti was replaced, probably because of his numerous commitments, by the engineer of Acque e Strade Antonio Coppola, who was in charge of checking the progress of the works.

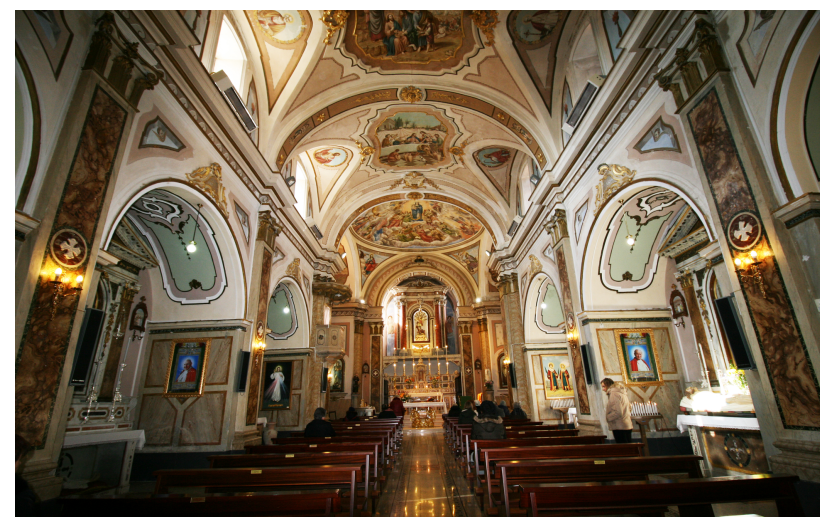

Figure 5. Sant'Elena Sannita (Isernia). Church of St. Michele Arcangelo: the main nave (Romano, 2016).

12 State Archive of Campobasso, Intendenza di Molise, b. 550, f.lo 25.

13 "Pietre di poco peso, volgarmente dette cimenti", State Archive of Campobasso, Intendenza di Molise, b. 523, f.lo 11, OO.PP. 18071835. Perizia del muratore Antonio Pallotta del 15 novembre 1815.

14 State Archive of Campobasso, Intendenza di Molise, b. 523, f.lo 11, OO.PP. 1807-1835. Perizia dell'ingegnere Domenicantonio Diodati del 1 maggio 1816.

15 State Archive of Campobasso, Intendenza di Molise, b. 339, f.lo s.n., Stato estimativo della spesa necessaria per la ricostruzione della chiesa Matrice del comune di Cantalupo, perizia di Nicolangelo Petitti, 27 ottobre 1828. 
From the documentation interesting data emerge, highlighting the technical awareness of the designers: iron chains to block the truss heads, connecting brackets and numerous other metalware works used for the reinforcement of the roof. The vaults were made up of cimenti while the arches of a mixed structure of bricks and cimenti ${ }^{16}$.

From the cases exposed, which clearly represent a partial and not exhaustive view of the overall diffusion of the technique, it is evident that the engineers who operated in the areas struck by earthquakes did not opt for new "different" building systems but actively and consciously implemented the local ones, following a well-established and, evidently, shared construction practice. In this regard, the combined use of bricks and cimenti for the construction of the arches and limestone for the abutments is of particular interest: each material was chosen for its characteristic and used to achieve the best result. The engineers, in addition to adopting the construction techniques widespread in the area, and inevitably linked to the availability of materials, reinterpreted, improved and adapted them to the different needs and situations.

\subsection{Tile and hollow clay pot vaults}

The other two elements employed for the construction of the vaults were full and hollow bricks. Some projects suggested adopting "bricks laid lengthwise with gypsum and counterforts" $" 17$ while others, as in the restoration works of the Collegio Sannitico of Campobasso, hollow clay pots (vasi figulini), known locally as pignatielli. Adding to the concepts presented in the previous paragraphs, this again testifies the extreme variety of construction techniques employed at the time, which were light and "adaptive" compared to preexisting structures in order to better respond against future earthquakes.

Terracotta was often used together with cimenti, when budget allowed it. As well as for the construction of the supporting arches of the barrel vaults, which in most cases cover the central naves of the analysed churches, bricks were also used for the construction of the entire vaulted systems. In this regard, it is opportune mentioning the vault in the church of Castropignano (Campobasso), built in 1814 in bricks bound with gypsum and white arena of Carpinone by the master builder Giacinto Catauro ${ }^{18}$. Francesco di Rienzo, master-builder of Agnone, in 1813 , instead, suggested to rebuild the vaults of the church of Salcito in «bricks laid lengthwise with gypsum and counterforts» ${ }^{19}$. This shines a light, once again, on the extreme variety of construction techniques that could be used for the reconstruction of the vaults. In particular, the choice of materials such as bricks adopted by two local master builders, supports the hypothesis that such construction system was widely spread and known since the 18 th century.

16 State Archive of Campobasso, Intendenza di Molise, b. 339, f.lo s.n., Perizia dell'Ingegnere Antonio Coppola, 3 scandaglio, 17 maggio 1833.

17 "mattoni per piano con gesso e contraforti", State Archive of Campobasso, Intendenza di Molise, b. 415, f.lo 11, Perizia della chiesa del comune di Castropignano, Giacinto Catauro, 30 giugno 1814.

18 State Archive of Campobasso, Intendenza di Molise, b. 415, f.lo 11, Perizia della chiesa del comune di Castropignano, Giacinto Catauro, 30 giugno 1814.

19 "mattoni per piano con gesso e contraforti", State Archive of Campobasso, Intendenza di Molise, b. 415, f.lo 11, Edifici pubblici, costruzione della chiesa madre 1813-1820. Perizia di Francesco di Rienzo, 16 dicembre 1813
"False brick vaults" were also provided for reconstruction project of the church of Belmonte del Sannio by the self-styled architect Gioacchino di Rienzo in $1823^{20}$. It is interesting to note that the vaults of the nave and side aisles were proposed in bricks since they were not intended to withstand distributed loads placed on the extrados. On the contrary, those of other rooms were designed "strong, in dead stone, greasy lime and sand" 21 , probably in view of the fact that they were provided for serving as attics for the upper floors. The controforti, elements often present in the examined documentation, on the other hand, could correspond to the transverse buttresses (frenelli) particularly common in the architectural heritage of Abruzzo (Varagnoli, 2008).

As pointed out by Enza Zullo, the use of brick is particularly widespread in the area of Campobasso and Bojano thanks to the rich presence of clayey soils (Zullo, 2008). This probably facilitated the use of this material for the realisation of the vaults, when economic conditions allowed it; in fact, it should be underlined that the brick vaults were more expensive than wooden ones. The presence of Abruzzese workers in the Province of Molise may also have contributed to the spread of this construction system, used in the nearby Abruzzo, especially following the 18th century earthquakes: the lightness of the material and the facility of implementation made it preferable to the more complex stone vaults (Varagnoli, 2008).

In addition to thin tiles flatly arranged, it should be highlighted the use of hollow clay pots, known in the Molise area as pignatielli, widespread in the ancient Province and in the current region both for the construction of vaults and floors and for non-load-bearing vertical partitions (Marino, Franchi, 1987; Marino, Tonietti, 2016).

Data available so far for the area under study do not allow a precise definition of the chronological period of use of the technique, which has its roots in the Roman-Byzantine vaulting systems and that is widespread throughout southern Italy. However, the archival documentation allows us to hypothesise a rather strong use throughout the 19th century and until the Second World War. It is a construction system that was widespread in many European countries from the end of the 18th century, partly thanks to the studies of Roman and Byzantine architecture by the most important architects and historians of the time, mainly French ${ }^{22}$.

It has to be underlined, on one hand, the presence of a "cultured" type of diffusion supported and favoured by the academic world. On the other hand, it is not to be excluded, especially in the context of central-southern Italy, a continuous use of the technique over the centuries due to a constructive wisdom preserved mainly by local master builders. In this regard, it is opportune highlighting how the terminology adopted helps to understand the "cultured" or vernacular origin of the design idea. In the case of the Collegio Sannitico in Campobasso, for example, the term used by the engineer Luigi Oberty to identify hollow clay pots was pignatini: this probably proves that the construction system was already partially known and used in the territory, hence the dialectal term ${ }^{23}$.

20 "Lamie finte a mattoni di piano e gesso", State Archive of Campobasso, Intendenza di Molise, b. 237, f.lo s.n. Restaurazione della chiesa di Belmonte 1822-1823. Perizia di Gioacchino di Rienzo architetto, 24 novembre 1822.

21 "forti, in pietre morte, calce grassa e arena".

22 For more information on the spread of the construction system in France see: Romano, 2019.

23 State Archive of Campobasso, Atti Notarili, Campobasso, Notaio Domenicantonio Doria D'Avvocati, b. 8, a. 1859. 
The Province of Molise, more than in Naples, the capital of the Kingdom, experienced these two streams of diffusion of the building system, which was in fact employed both in representative architecture and in rural buildings. Assuming that the building system had a certain continuity in its adoption over the centuries by local workers would help explaining both the terminology used - the dialect term pignatini - and the reason behind its use in minor architectures of uncertain date.

The use of four different materials - wood, cimento, bricks and hollow clay pots - demonstrates the strong integration of different building techniques and knowledge and proves the need to design light vaulted systems to be built not only on fragile pre-existing masonry but also on ex-novo buildings.

\section{CONCLUSIONS: WHICH RESILIENCE?}

In relation to the seismic area of Molise, it appears of great interest the analysis of the interventions implemented in the past, taking into account the degree of knowledge that can be inferred from them. In many cases, in fact, as after the 1805 earthquake, the technicians called upon to intervene, proposed 'adaptive' solutions that took into account the intrinsic characteristics of the structures and the need to not overload the pre-existing fragile vertical partitions. This choice could have been dictated by the desire to reduce the vulnerability of the built system at the architectural scale, which could be achieved by increasing its adaptive capacity. The realisation of 'light' vaulted systems represented, therefore, the best solution - in view of the intrinsic nature of this type of flooring - capable of not generating, in the event of possible further earthquakes, the overturning of the masonries due to the lateral pushing forces.

It should be noted, however, that the limited thicknesses of most of the vaults under investigation, with the exception of the concrete ones, can represent, in the event of an earthquake, a structural vulnerability factor. In fact, it could contribute to the formation of plastic hinges and to consequent collapses of the structures, due to the great probability of the pressure line exiting from the thickness of the vaults.

The earthquake that struck the eastern side of Molise in 2002, with epicentre in San Giuliano di Puglia (Campobasso) clearly highlighted some of the intrinsic vulnerability factors of historical buildings (Podesta, Lagomarsino, 2004; Lagomarsino et al., 2004a; Lemme, Podestà, 2004; Lagomarsino et al., 2004b; Cifani et al., 2005). Although the epicentre and the concerned towns were not the same as those affected by the earthquake of 1805 , the similarities in the construction features of the architectural heritage, in particular the ecclesiastical buildings, allows to analyse the applicability of potential seismic improvement projects.

In particular, the 2002 earthquake highlighted how some interventions to strengthen the structures, carried out since the second half of the 20th century, contributed to the increase in the vulnerability of the built heritage due to their incompatibility with the pre-existing structures (Podestà, Lagomarsino, 2004). The replacement of wooden roofs with side-cement ones, the insertion of reinforced concrete edgebeams and reinforced concrete layers at the extrados of the vaults proved to be some of the main drivers behind the formation of mechanisms of instability during the earthquake. The excessive weight of reinforced concrete roofs, for example, led to the crushing of the vertical support partitions and the consequent collapse of the vaults connected to them.
It is interesting to point out that most of the vaulted systems of the churches damaged in the 2002 earthquake were characterised by a limited thickness (from 5 to 10 centimetres) and were made of thin bricks and hollow clay pots (Cifani et al., 2005). The circumscribed size of the resistant section of the vaults, together with the absence of stiffening chains has, in many cases, led to their total or partial collapse without, however, affecting the resistant capacity of the vertical partitions or contributing to their overturning. Albeit highly vulnerable, the 'light' and, in this case, thin vaulted systems showed to be 'adaptive' both in static and, partially, in dynamic regimes. In the latter case, the boundary conditions contributed to the improvement or worsening of the structure's behaviour: for example, if the chains, placed both transversely and longitudinally, helped to contain the thrusts of the vaults and improved their behaviour, the presence of contact elements between the roofs and the vaulted systems facilitated the transmission of concentrated loads capable of generating local instabilities.

An emblematic case referable to the interventions carried out following the earthquake of 1805 is represented by the vault of the nave of the church of San Michele Arcangelo in Baranello, in the province of Campobasso. The possibility of making a direct analysis of the structure and its extrados allows the identification of the structural vulnerability factors. The vault - made up of a slender wooden and reed frame, covered with a cast of conglomerate of lime and gypsum - is partially suspended from the wooden truss and, therefore, in case of movement of the same, subject to possible phenomena of local instability. It would be appropriate, therefore, to evaluate the possibility of isolating the two systems in order to avoid potential instabilities and to consider to what extent the use of Fiber Reinforced Polymers (FRP) could contribute to the effective improvement of the behaviour of the structure or, on the contrary, trigger possible future collapses.

The same considerations are also valid for tile vaulting. In this case the thickness of the vaulted system, determined by the number of layers of bricks used, represents a factor of great importance that influences the behaviour of the structure in dynamic regime. The tile vaults, belonging to the family of cohesive structures, are characterised by a monolithic behaviour. They are able to withstand distributed loads but not concentrated ones, inducing flexural forces in the system, capable of generating localised failure (Giuriani, Marini 2008). In the case of vaults consisting of a single layer of bricks, as in many cases in Molise, there is a higher probability that the pressure line may exit from the resistant section of the structure causing plastic hinges.

At the architectural scale, the possible presence of anti-seismic devices, first of all chains, arranged both transversally and longitudinally, represents a solution able to counteract the phenomena of overturning of facades and, therefore, the consequent collapses of the vaults, also caused by the hammering of the roofs. The presence of buttresses (frenelli), observable on the extrados of tile vaults in Molise, helps to ensure resistance and to absorb the thrust, thus constituting a valid device in case of earthquake.

In relation to hollow clay pots vaults, research conducted so far has highlighted their membrane-like behaviour and a good resistance to distributed loads (Marino, Franchi, 1987; Pierotti 1989; Marino, Tonietti 2016). In this case, as for tile vaults, the collapse mechanisms, in the event of an earthquake, can be caused by possible overturning of the vertical partitions or by 
local instability phenomena induced by potential transfers of concentrated loads from the roofing above. Although Fiber Reinforced Polymers (FRP) are often used in current practice and consolidation projects, it seems appropriate to precede this type of proposal by a careful analysis of the construction system, considering the issues related to the chemical, physical and mechanical compatibility.

In conclusion, it may be pointed out the scarce role of lightweight vaults in the mechanisms of collapse generated during earthquakes, in spite of their intrinsic weaknesses, mainly due to their limited thickness. In fact, these types of vaults contribute only minimally to the generation of thrusts on the vertical partitions and are therefore not responsible for the overturning or collapsing of the masonries. The effects and the damages on the architectural heritage caused by the 2002 earthquake proved how these vaults are less dangerous than the so-called heavy vaults and how a good knowledge of these structures is important for a responsible restoration project.

\section{REFERENCES}

Antinori, A., 2006. La ricostruzione in Molise dopo il terremoto del 1805: una ricerca sul territorio, in Antinori, A. (ed.) Da Contado a provincia. Città $e$ architettura in Molise nell'Ottocento preunitario, Roma, Gangemi, 49-80.

Antinori, A., 2007. Sopralluoghi in Molise. La ricostruzione dopo il terremoto del 1805, in Cantone, G., Marucci, L., Manzo, E., (eds), Architettura nella storia. Scritti in onore di Alfonso Gambardella, Milano, Skira, 619-629.

Carocci, C.F., Tocci, C., Le tecniche costruttive nella ricostruzione post 1703 a L'Aquila, in Nobile, M.R., Scibilia, F. (eds), Tecniche costruttive nel Mediterraneo. Dalla stereotomia ai criteri antisismici, Palermo, Edizioni Caracol, 163-178.

Cifani, G., Lemme, A., Podestà, S. (eds), 2005. Beni monumentali e terremoto. Dall'emergenza alla ricostruzione, Roma, DEI Tipografia del Genio Civile.

de Vegni, L.M. 1788. Volte leggieri con materiali naturali, Memorie per le belle arti, IV, LXXXV-C.

Fortini, P. 1984. Delle cause de' terremoti e loro effetti. Danni di quelli sofferti dalla citta d'Isernia fino a quello de' 26 luglio 1805, s.l., Isernia s.d. (anastatic reprint by Sardelli, T., Isernia, Marinelli), section IX: Delle altre devastazioni della Città d'Isernia e sue riedificazioni.

Ghisetti Giavarina, A., 2016. L'Aquila. Tecniche costruttive antisismiche prima e dopo il terremoto del 2 febbraio 1703, in Nobile, M.R., Scibilia, F. (eds), Tecniche costruttive nel Mediterraneo. Dalla stereotomia ai criteri antisismici, Palermo, Edizioni Caracol, 153-162.

Giuriani, E., Marini, A., 2008. Experiences from the Northern Italy 2004 earthquake: vulnerability assessment and strengthening of historic churches, in Proceedings of the VI International Conference on Structural Analysis of Historical Constructions SAHC (Bath, July $2^{\text {nd }}-4^{\text {th }}, 2008$ ), London, Ed. Taylor and Francis, 13-24
Lagomarsino, S., Podestà, S., Lemme, A., 2004a. Il terremoto del 31 Ottobre 2002 in Molise: una nuova metodologia per il rilievo dei danni e della vulnerabilità sismica delle chiese, in «L'ingegneria Sismica in Italia», Proceedings of the XI National congress, Genova.

Lagomarsino, S., Lemme, A., Podestà, S., 2004b. Rilievo del danno al patrimonio monumentale dopo il terremoto dei 2002 in Molise e Puglia, Ingegneria Sismica, 2, 7-19.

Lemme, A., Podestà, S., 2004. La messa in sicurezza degli edifici monumentali in Molise a seguito della crisi sismica iniziata il 31.12.2002: valutazione della permanenza nel tempo delle puntellature alle chiese, Isernia, Report Regione Molise.

Marino, L., Franchi, R., 1987. Notizie su alcune strutture leggere apparecchiate con tubi fittili ("pigniatielli") e indagine mineralogico-petrografiche, in Biscontin, G., Angeletti, R. (eds), «Conoscenze e sviluppi teorici per la conservazione di sistemi costruttivi tradizionali in muratura», Proceedings of the Conference Scienza e Beni culturali (Bressanone, June, $23^{\text {rd }}$ $\left.26^{\text {th }}, 1987\right)$, Padova, Libreria Progetto, Padova, 101-112.

Marino, L., Tonietti, U., 2016. L'opus caccabaceum, une singulière maçonnerie légère en terre cuite, in Fleury, F., Baridon, L., Mastorilli, A., Mouterde, R., Reveyron, N., (eds), Les temps de la construction : processus, acteurs, matériaux, Proceedings of the deuxième Congrès francophone d'histoire de la construction (Lyon, January, $29^{\text {th }}-31^{\text {st }}, 2014$ ), Paris, Picard, $37-45$.

Nobile, M.R., 2004. Cupole e calotte "finte" nel XVIII secolo, in Gambardella, A. (ed.), Ferdinando Sanfelice. Napoli e l'Europa, Edizioni Scientifiche Italiane, Naples, 151-162.

Nobile, M.R., Bares, M.M., 2015, The use of 'false vaults' in 18th century buildings of Sicily, Construction History, vol. 30, n. $1,53-70$.

Penta, F., 1935. I materiali da costruzione nell'Italia meridionale. Molise, Puglia, Lucania, Calabria e appendice al primo volume, Napoli, Fondazione Politecnica del Mezzogiorno, vol. II, 258-259.

Pierotti, P., 1989. Il caso della bubbola assassina, in Ferrigni, F., (ed.), San Lorenzello. Alla ricerca delle anomalie che proteggono, Ravello, Centro Universitario Europeo per i Beni Culturali, 93-97.

Podestà, S., Lagomarsino, S., 2004, Damage and Vulnerability Assessment of Churches after the 2002 Molise, Italy, Earthquake, Earthquake Spectra, 20, 271-284.

Romano, L. 2016a, Dentro la catastrofe. Il terremoto del 1805 tra emergenza e prima remissione dei danni a Napoli e in Terra di Lavoro, Storia Urbana, 152-153, 59-68.

Romano, L. 2016b, Catastrofe come lento mutamento. Il terremoto del 1805 e le dinamiche di trasformazione del paesaggio e dell'architettura molisana, in Capano, F., Pascariello, M.I., Visone, M. (eds), Delli aspetti de' paesi. Rappresentazione, memoria, conservazione, Napoli, CIRICE, vol. II, 415-424. 
Romano, L., 2018. Tra arte e scienza. Dal danno sismico alla sperimentazione di sistemi voltati 'leggeri' nel Regno delle Due Sicilie tra tardo Settecento e prima metà dell'Ottocento, (Ph.D Thesis, Università degli Studi di Napoli Federico II, XXX cycle, supervisors: prof.arch. Valentina Russo and prof.arch. Alfredo Buccaro), chapter 4, 179-245.

Romano, L., 2019. Voûtes légères. La technique de construction en poterie creuse en France et en Italie aux XVIIIe et XIXe siècle', in Bienvenu, G., Monteil, M., Rousteau-Chambon, H. (Eds), Construire! Entre Antiquité et Époque contemporaine, Proceedings of the $3^{\text {rd }}$ Congrès Francophone d'Histoire de la Construction (Nantes June $21^{\text {st }}-23^{\text {rd }}, 2017$ ), Paris, Picard, 11791187.

Scibilia, F., 2016. Il terremoto del 1823 in Sicilia e settentrionale: danni e ricostruzioni, in Nobile, M.R., Scibilia, F. (eds), Tecniche costruttive nel Mediterraneo. Dalla stereotomia ai criteri antisismici, Palermo, Edizioni Caracol, 179-194.

Serafini, L., 2009. Terremoti e architetture in Abruzzo. Gli espedienti antisismici del cantiere tradizionale, in Varagnoli, C. (ed.), Muri parlanti. Prospettive per l'analisi e la conservazione dell'edilizia storica, Proceedings of conference (Pescara, September $\left.26^{\text {th }}-27^{\text {th }}, 2008\right)$, Firenze, Alinea editrice, 221-236.

Valadier, G., 1828-39. L'architettura pratica dettata nella scuola e cattedra dell'insigne accademia di San Luca, Roma, Società Tipografica, Roma, vol. IV, 4.

Varagnoli, C., 2008. Tecniche e materiali nella costruzione delle volte in Abruzzo, in Varagnoli, C., (ed.), La costruzione tradizionale in Abruzzo. Fonti materiali e tecniche costruttive dalla fine del Medioevo all'Ottocento, Roma, Gangemi editore, 49-64.

Zullo, E., 1996. La cattedrale di Isernia. Il monumento simbolo della città: origini, distruzioni e restauri attraverso i secoli, Venafro, Vitmar.

Zullo, E., 2008. Tra Abruzzo, Napoli e Puglia: tecniche murarie nell'edilizia storica del Molise, in Varagnoli C. (ed.), Terre murate. Ricerche sul patrimonio architettonico in Abruzzo e Molise, Roma, Gangemi Editore, 75-96.

Zullo, E., 2009. Architettura e protagonisti della ricostruzione in Molise dopo il terremoto del 1805. In Zullo, E., (ed.) Architettura $e$ terremoto in Molise. Proceedings of the conference «Il Molise, il terremoto e la festa di S. Anna» (Pescolanciano, July 2 ${ }^{\text {nd }}, 2005$ ), Campobasso, Palladino, 41-90. 